\title{
Diagnosis of chronic osteomyelitis complicated with mycotic infection
}

\author{
A.S. Sudnitsyn, N.M. Kliushin, N.S. Migalkin, T.A. Stupina, T.N. Varsegova, Z.S. Naumenko, \\ V.D. Gayuk
}

Russian Ilizarov Scientific Center for Restorative Traumatology and Orthopaedics, Kurgan, Russian Federation

\begin{abstract}
Introduction In the last decade, there has been an increase in the incidence rate of mycoses in patients after injuries and/ or operations performed on limb segments and major joints. Mycoses are difficult to diagnose early because the mycotic flora may mimic the bacterial flora being present in the osteomyelitic nidus and primarily identified in the wound exudate. Objective To develop diagnostic criteria for osteomyelitis complicated with mycotic infection. Methods We performed a retrospective study of 28 patients (17 males and 11 females) aged 21 to 76 years (49 \pm 16 years) who were treated for purulent inflammatory lesions of bones and/or joints at the clinic of osteology infection between 2000 and 2018. Results Mycotic infection was pathomorphologically detected in the osteomyelitis nidus of all patients. Patients were treated according to the established protocol including radical sequestrectomy, diagnostic biopsy and postoperative administration of antimicrobial and antifungal therapy. Discussion The study allowed identification of several diagnostic criteria for osteomyelitis complicated by mycotic infection. Pathomorphological examination of surgical specimen from purulent inflammatory nidus was shown to be the keystone in diagnosis of osteomyelitis complicated with mycoses.

Keywords: osteomyelitis, mycotic infection, diagnosis of osteomyelitis of mycotic etiology
\end{abstract}

\section{INTRODUCTION}

Treatment of chronic osteomyelitis remains a clinical challenge [1, 2, 3]. Trauma-induced osteomyelitis remains the most common cause with infection rates in open long bone fractures ranging between 5.3 and $75.4 \%$ [1, 2]. Osteomyelitis can be associated with the iatrogenic introduction of infection due to inappropriate surgical options used to repair the injured bone. The risk of infection following IM nailing and plating is reported to range between $5 \%$ and $17 \%$ [1-4]. On the other hand, prosthetic joint infections represent a relatively new entity of chronic osteomyelitis. Their incidence is reported to be as high as $1 \%$ to $4 \%$ [5]. The standard treatment of chronic osteomyelitis involves thorough debridement of infected bone, options to retain or remove the infected implant and replace it with different hardware, and systemic antibiotic administration [1, 5, 6, 7]. Often patients with chronic osteomyelitis receive prolonged antibiotic therapy with high doses rather than debridement for removal of all infective and necrotic material [2, 3]. Antibiotics might need to be replaced in some cases when antimicrobial therapy starts before cultures have been obtained, usually at the time of debridement [1, 2, 3, 5, 6, 7].

Although all types of organisms may cause osteomyelitis bone infections are commonly caused by certain bacterial flora. In the last decade, there has been an increase in the incidence rate of mycoses in patients after injuries and/or operations performed on limb segments and major joints [9-17]. Mycoses are difficult to diagnose early [8-17]. The mycotic flora may mimic the bacterial flora being present in the osteomyelitic nidus and primarily identified in the wound exudate. This results in prolonged antibiotic therapy without use of antifungal medicines and finally leads to repeated revision procedures [917]. Such a continuous inadequate treatment can reduce immune system response, promote growth of persistent bacterial strains and spread of fungal infection. Therefore, early diagnosis of mycotic infection is important for optimizing treatment outcomes of chronic osteomyelitis.

Objective The purpose of the study was to develop diagnostic criteria for osteomyelitis complicated with mycotic infection.

Cal Sudnitsyn A.S., Kliushin N.M., Migalkin N.S., Stupina T.A., Varsegova T.N., Naumenko Z.S., Gayuk V.D. Diagnosis of chronic osteomyelitis complicated with mycotic infection. Genij Ortopedii, 2019, vol. 25, no 4, pp. 528-534. DOI 10.18019/1028-44272019-25-4-528-534. (In Russian) 


\section{MATERIAL AND METHODS}

We performed a retrospective study of 28 patients (17 males and 11 females) aged 21 to 76 years ( $49 \pm 16$ years) who were treated for purulent inflammatory lesions of bones and/or joints at the clinic of osteology infection between 2000 and 2018. The study was performed in accordance with ethical principles for medical research involving human subjects stated in the Declaration of Helsinki developed by the World Medical Association as revised in 2013. Written informed consent was obtained from all patients for publication of the findings without identifying details.

Preoperative radiological examination was performed for all patients using RADIOTEX radiography system, registration certificate FS № 2006/527; RAYMAT ASI, registration certificate FS № 2006/2099; CLINOMAT, registration certificate FS № 2006/559. Preoperative ultrasound was produced for 16 patients using AVISUS Hitachi ultrasound scanning system (Japan) and $7.5 \mathrm{MHz}$ linear transducer. Duplex scanning provided images of vessels, measurement of blood flow velocity and spectrum analysis. An area of metatarsal metaphysis was referred to as a control ( $\mathrm{AP}=210 \pm 10 \mathrm{CU}$ ).

Intraoperative wound sampling was performed for microbiological studies. Nutrient agar containing
$5 \%$ of blood, egg-yolk salt agar, Levine medium, Sabouraud agar growth medium were used to cultivate aerobic and facultative anaerobic bacteria. Cultures grew at $37^{\circ} \mathrm{C}$ for $24-48$ hours. Bacterial counts in clinical isolates were measured using solid agar culture media in accordance with procedural guidelines using decimal logarithm of evolved colonies $(\mathrm{CFC} / \mathrm{mL})$. Bacterial cultures were generically and specifically identified with conventional techniques to explore their tinctorial, cultural and biochemical characteristics, and ATB Expression Bacteriology analyzers (Bio Merieux, France), Walk Away 40 Automated Microbiology Assay System (USA) and WHONET 5.6 Microbiology laboratory database software [19]. Involved bone fragments, sequesters and the skin excised during surgical debridement were histologically examined. Specimen were fixed in neutral buffered formalin, decalcified and embedded in paraffin. Histological preparations (paraffin sections of $5-7 \mathrm{mcm}$ cut with Reichard sledge microtome (Germany) were stained with hematoxylin and eosin, Pappenheim method and periodic acid Schiff for neutral mucopolysaccharides. Images of micropreparations were acquired with AxioCam digital camera, AxioScope.A1 microscope and Zen blue software (Carl Zeiss MicroImaging $\mathrm{GmbH}$, Germany).

\section{RESULTS}

An injury to a limb and/or surgical intervention performed on one or several segments complicated with purulent infection was reported in medical records of all patients. Average infection duration was 11 years (range, 1-44 years). Patients received repeated courses of antimicrobial therapy, local treatment and several patients underwent 1 to 4 debridement interventions (Table 1).

Patients presented with disturbed supportability of a limb, wounds and/or sinuses on admission. Localization of necrotic foci is presented in Table 2. Some patients experienced long periods of high body temperature.

Physical examination of the patients revealed postoperative and/or posttraumatic scars, functioning wounds, ulcers and/or sinuses. Some patients had swollen soft tissues, cyanosis of the skin, disturbed capillary refill and weak arterial pulse wave (Table 3).

Ultrasound evaluation showed stenosis of major vessels at different levels $(n=4)$, weak magistral blood flow and open collaterals $(n=9)$, and no changes in hemodynamics revealed in three cases. Onychomycosis was diagnosed in all patients with disturbed magistral blood flow $(\mathrm{n}=13)$ (Table 3). All patients had comorbid diseases with cardiovascular, gastrointestinal, urinogenital and spinal cord injuries being most common (Table 4).

Table 1

Treatment performed for patients with chronic osteomyelitis prior to admission to the Clinic of Osteology Infection

\begin{tabular}{|c|c|c|}
\hline \multicolumn{2}{|c|}{$\begin{array}{c}\text { Number and type of surgeries performed prior to admission to } \\
\text { the Clinic of Osteology Infection }\end{array}$} & \multirow[t]{2}{*}{$\begin{array}{l}\text { Antimicrobial therapy received by the patients prior } \\
\text { to admission to the Clinic of Osteology Infection }\end{array}$} \\
\hline Type of intervention & Number of observations & \\
\hline Orthopaedic procedure & 19 & 13 \\
\hline Sequestrectomy & 9 & 9 \\
\hline
\end{tabular}


Localization of necrotic focus

\begin{tabular}{|l|c|}
\hline \multicolumn{1}{|c|}{ Localization of necrotic nidus } & $\begin{array}{c}\text { Number of } \\
\text { patients }\end{array}$ \\
\hline Foot & 10 \\
\hline Femur & 6 \\
\hline Tibia & 1 \\
\hline Hip joint (periprosthetic joint infection) & 4 \\
\hline Knee joint (periprosthetic joint infection) & 3 \\
\hline Pelvis, spine (sacrum) & 3 \\
\hline Clavicle & 1 \\
\hline
\end{tabular}

Table 3

Physical examination of patients

\begin{tabular}{|l|c|}
\hline \multicolumn{1}{|c|}{ Physical findings } & $\begin{array}{c}\text { Number of } \\
\text { observations }\end{array}$ \\
\hline Wounds/ulcers & 12 \\
\hline Sinuses & 18 \\
\hline Lacerations & 9 \\
\hline Scars & 19 \\
\hline Hyperkeratosis & 9 \\
\hline Edema & 11 \\
\hline Hyperemia, cyanosis, paleness & 3 \\
\hline Psoriatic plaques & 1 \\
\hline Positive capillary refill test & 3 \\
\hline Weak pulse in major vessels & 22 \\
\hline Onychomycosis & 13 \\
\hline
\end{tabular}

Immune related diseases were diagnosed in 10 patients ( $34 \%$ ) who underwent immunosuppresive therapy. Radiographic examination of the majority of patients showed bone destruction (osteolysis), bone sequesters, periostitis, exostoses and sclerosis (Table 5). Foreign bodies (implants) could be visualized the articular cavity in cases of deep periprosthetic joint infection along with periostitis and bone defects. Arthritis of adjacent joints could be seen in patients with infection localized in the metaphyses (Table 5).

Preoperative laboratory blood tests showed signs of inflammation with leukocytosis, neurophilic imbalance, accelerated erythrocyte sedimentation rate, elevated C-reactive protein level (Table 6).
Comorbid conditions in patients with chronic osteomyelitis

\begin{tabular}{|l|c|}
\hline \multicolumn{1}{|c|}{ Comorbidities } & $\begin{array}{l}\text { Number of } \\
\text { observations }\end{array}$ \\
\hline Hypertension & 12 \\
\hline CAD. Coronary artery disease, CHF & 2 \\
\hline $\begin{array}{l}\text { Congenital angiodysplasia (Parkes-Weber- } \\
\text { Rubashov syndrome) }\end{array}$ & 1 \\
\hline Anemia & 5 \\
\hline Lower extremity varicose vein disease, CVI & 1 \\
\hline PUD, duodenal ulcer, gastritis & 3 \\
\hline $\begin{array}{l}\text { Drug-induced liver injury with minimally } \\
\text { decreased function }\end{array}$ & 1 \\
\hline Chronic colitis & 1 \\
\hline DM & 2 \\
\hline Obesity & 2 \\
\hline $\begin{array}{l}\text { TSCI, flaccid lower paraplegia. Pelvic floor } \\
\text { dysfunction }\end{array}$ & 5 \\
\hline Chronic prostatitis & 1 \\
\hline Bladder stone disease & 2 \\
\hline Chronic pyelonephritis & 3 \\
\hline Hypoplastic kidneys & 2 \\
\hline Chronic bronchitis, remission, fungi & 3 \\
\hline U.R.I. & 1 \\
\hline Chronic hepatitis C & 3 \\
\hline Hepatitis B & 1 \\
\hline $\begin{array}{l}\text { Chronic herpes virus infection, latent } \\
\text { period. CMV, toxoplasmosis }\end{array}$ & 1 \\
\hline HIV & 1 \\
\hline Psoriasis & 1 \\
\hline Osteogenic sarcoma & 1 \\
\hline $\begin{array}{l}\text { Breast cancer (left side) following operative and } \\
\text { Rg treatment. Lymphostasis of the left upper limb }\end{array}$ & 1 \\
\hline
\end{tabular}

Table 5

Characteristic radiological picture in patients with chronic osteomyelitis

\begin{tabular}{|l|c|}
\hline \multicolumn{1}{|c|}{ Radiographic manifestations } & $\begin{array}{c}\text { Number of } \\
\text { observations }\end{array}$ \\
\hline Osteolysis/destruction/osteoporosis & 19 \\
\hline Osteophytes, exostoses & 15 \\
\hline Osteolysis/sequestrum & 7 \\
\hline Periosteal reaction & 15 \\
\hline Changes in articular surfaces & 4 \\
\hline Bone cysts, cavities & 3 \\
\hline Osteosclerosis & 13 \\
\hline Foreign bodies (implants) & 8 \\
\hline
\end{tabular}

Table 6

Laboratory blood tests in patients with chronic osteomyelitis

\begin{tabular}{|c|c|c|}
\hline \multicolumn{3}{|c|}{ Inflammation markers } \\
\hline Blood parameter & $\%$ of increase $(\mathrm{n})$ & Median (range) \\
\hline WBC $\left(/ \mathrm{mm}^{3}\right)(\mathrm{WBC})$ & $>10.000 / \mathrm{mm}^{3} ; 45 \%(\mathrm{n}=28)$ & $9.270(100-37.000)$ \\
\hline PMNs $(\%)($ neutrophils $)$ & $>80 \% ; 30 \%(\mathrm{n}=28)$ & $79.3(10.3-90)$ \\
\hline ESR $(\mathrm{mm} / \mathrm{h})$ & $>15 \mathrm{~mm} / \mathrm{hr} ; 96 \%(\mathrm{n}=28)$ & $86(10-148)$ \\
\hline CRP $(\mathrm{mg} / \mathrm{dl})$ & $>1 \mathrm{mg} / \mathrm{dL} ; 100 \%(\mathrm{n}=28)$ & $51.5(1.5-151)$ \\
\hline
\end{tabular}


The majority of the patients underwent one and more operative interventions and received repeated courses of antimicrobial therapy, so we examined perioperative biopsy samples taken from infection nidus to identify microflora. In addition to that, perioperative biopsies were obtained to detect mycotic infection, and fungal colonization of Candida species was isolated from specimen of 3 cases out of 28. Types of pathogens cultured are presented in Table 7. Staphylococcus aureus, S. epidermidis, Pseudomonas aeruginosa were shown to be most common organisms causing osteomyelitis, whereas other atypical organisms were identified as monocultures and microbial associations less frequently.

Pathohistological examination of biopsy samples and operation material taken from the involved sites showed signs of mycotic microflora with yeastlike cells and pseudomicellar structures seen in the specimen (Fig. 1).

Inflammatory reaction was identified in both infiltration and production forms depending on the type of organism. All patients with chronic osteomyelitis were treated according to the established protocol with reference to individual clinical manifestations. Radical sequestrnecrectomy and biopsy sampling were produced in all cases. Ilizarov bone fixation $(\mathrm{n}=13)$ was performed and cemented spaces implanted $(n=7)$. All patients received etiotropic antimicrobial therapy administered postoperatively for 2-4 weeks. With pathomorphological findings available all patient were administered additional antifungal therapy including itrakonazole $(\mathrm{n}=10)$, fluconazole $(n=14)$, amphotericin B $(n=4)$. Ilizarov bone transport was produced to repair bone defect $(n=3)$ with purulent infection arrested. Despite the treatments performed (Table 8) two patients developed recurrent osteomyelitis at one-year follow-up. Recurrence was observed at 1 to 3 years in 13 patients. And 3 patients had a recurrence at 3 years and over. The recurrences were treated with radical debridement, antimicrobial and antifungal therapies. Persistent quiescence was postoperatively achieved in all patients.

Microflora of mycotic etiology detected in patients with chronic osteomyelitis

\begin{tabular}{|c|c|c|}
\hline \multicolumn{2}{|c|}{ Types of pathogen } & \multirow{2}{*}{$\frac{\text { Number of observations }}{15}$} \\
\hline \multirow{10}{*}{ Gram-positive bacteria } & Staphylococcus aureus & \\
\hline & Staphylococcus epidermidis & 8 \\
\hline & Staphilococcus hominis subsp & 1 \\
\hline & Staphylococcus saprophyticus & 2 \\
\hline & Staphylococcus haemolyticus & 1 \\
\hline & Streptococcus pyogenes & 1 \\
\hline & Bacillus spp. & 1 \\
\hline & Actinomycos spp. & 1 \\
\hline & Enterococus faecalis & 6 \\
\hline & Corynebacterium spp. & 2 \\
\hline \multirow{10}{*}{ Gram-negative bacteria } & Myroides sp. & 1 \\
\hline & Stenotrophomonas maltophilia & 1 \\
\hline & Enterobacter cloacae & 3 \\
\hline & Pseudomonas aeruginosa & 15 \\
\hline & Alcaligenes sp. & 3 \\
\hline & Leuconostoc sp. & 1 \\
\hline & Escherichia coli & 8 \\
\hline & Proteus mirabilis & 7 \\
\hline & Achromobacter xilosoxidans & 1 \\
\hline & Klebsiella pneumoniae & 3 \\
\hline Fungi & Candida spp. & 3 \\
\hline
\end{tabular}




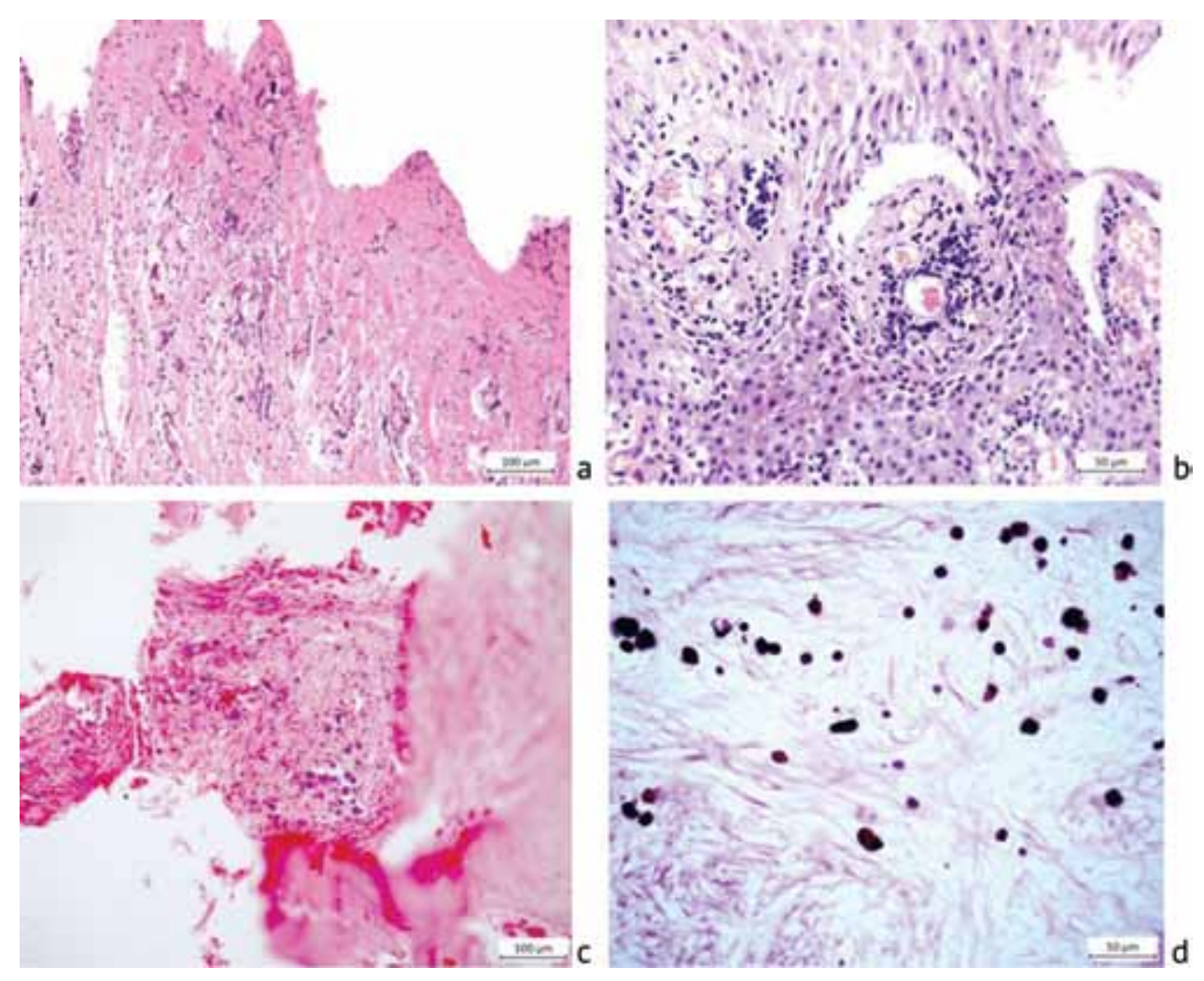

Fig. 1 Signs of mycotic process in the specimen $(\boldsymbol{a})$ seen at the edge of the defect, pseudomicelium net, $(\boldsymbol{b})$ yeast-like flora, $(\boldsymbol{c}, \boldsymbol{d})$ blastomycosis, yeast-like cells at the site of productive inflammation. Magnification: $(\boldsymbol{a}, \boldsymbol{c}) \times 250 ;(\boldsymbol{b}, \boldsymbol{d}) \times 500$. Stained with hematoxylin\&eosin $(\boldsymbol{a})$, Pappenheim method $(\boldsymbol{b}, \boldsymbol{c})$, periodic acid Schiff $(\boldsymbol{d})$

Table 8

Long-term follow-ups of patients with chronic osteomyelitis

\begin{tabular}{|c|c|c|}
\hline Follow-up & Quiescence & Recurrence \\
\hline Up to one year & 26 & 2 \\
\hline $1-3$ years & 15 & 13 \\
\hline 3 years and over & 25 & 3 \\
\hline
\end{tabular}

\section{DISCUSSION}

Our series allowed identification of several diagnostic criteria for osteomyelitis complicated with mycotic infection. In our opinion and according to M.N. Gamaletsou et al. (2014), L.C. Ferreira, (2016), R. Clemence et al. (2017), chronic purulent inflammation process, repeated courses of antimicrobial therapy and operative interventions reported in medical history of a patient can be considered as one of causative factors and diagnostic criteria for chronic osteomyelitis [9-17]. Decrease in blood supply plays a role in the development of mycosis. C. Richaud et al. (2017) reported a series of 28 patients with mycosis who developed ischemia of the involved limb in most of the cases. Immunosuppression from hormone, chemotherapeutic agents used for oncologic and autoimmune diseases, hemodialysis and organ transplantation is a risk factor for mycosis. Immunodeficiency caused by HIV is another contributing factor [11-17]. The studies performed by the International Working Group on the Diabetic Foot showed that mycosis was detected along with bacterial flora in some diabetic patients [18]. Osteolysis combined with excessive periosteal reaction was shown to be the principal radiological criteria for diagnosis of chronic osteomyelitis in mycotic patients (Jain R., 2014). However, the above radiological manifestations are likely to be an indication of metaplastic process $[11,14,15,16]$.

In our opinion and according to Cohen S.H. et al. (2010), Jain R. et al. (2014), Gamaletsou M.N. et al. (2014) microbial flora being present at the site of purulent inflammation as low pathogenic organisms of monoinfection and microbial associations can be one of manifestations of mycotic infection in the 
nidus. The series reported by Cohen S.H. et al. (2010), Jain R. et al. (2014), Gamaletsou M.N. et al. (2014) analyzed dynamics in microbial flora in osteomyelitic focus of mycotic patients and revealed pathogenic flora being replaced with conventionally pathogenic flora due to mycotic invasion $[11,14,15,16]$. Pathomorphological examination of biopsy sample at the nidus of purulent infection is the basic diagnostic criterion. Diagnostic biopsy can be produced as part of preoperative preparation of the patient [9-17]. Risk grading scale for mycosis was developed with the above factors in mind marking presence/absence of the signs in the right-hand column (Table 9).

With $50 \%$ positive answers diagnostic biopsy at the site of purulent inflammation can be recommended as part of preoperative preparation.

Table 9

Risk grading scale for mycosis in osteomyelitic nidus

\begin{tabular}{|l|l|}
\hline Diagnostic criterion & $+/-$ \\
\hline Long-term history of the disease & \\
\hline Immunosuppression, diabetes mellitus & \\
\hline Radiologically: non-specific osteolysis, periosteal reaction & \\
\hline Microbiologically atypical microflora & \\
\hline Angiopathy, ischemia of the limb & \\
\hline Extensive scars of soft tissues of the involved limb & \\
\hline
\end{tabular}

\section{CONCLUSION}

1. Unfavorable course of purulent infection (duration, recurrence, atypical clinical manifestations, multiple failures in antimicrobial therapy) necessitates additional diagnostic procedures and their adequate assessment.

2. Success of positive outcomes with mycosis and osteomyelitis relies on adequate diagnosis providing a complex approach to radical surgical debridement and targeted etiotropic antimicrobial and antifungal therapy.
3. With high risk of mycosis identified at the osteomyelitic nidus biopsy sampling is practical.

4. Pathomorphological examination of biopsy sample is the basic diagnostic criterion.

5. Possibilities with successful treatment of mycosis have been extended due to effective and safe antifungal agents being available in recent years.

\section{REFERENCES}

1. Novomlinskii V.V., Malkina N.A., Andreev A.A., Glukhov A.A., Mikulich E.V. Sovremennye aspekty diagnostiki i lecheniia osteomielita. Obzor literatury [Modern aspects of osteomyelitis diagnosis and treatment. Review of the literature]. Sovremennye Problemy Nauki i Obrazovaniia, 2016, no. 5. (in Russian) Available at: http://www.science-education.ru/ru/article/view?id=25326 (accessed 09.06.2019).

2. Vinnik Iu.S., Markelova N.M., Shageev A.A. Khronicheskii osteomielit: diagnostika, lechenie, profilaktika [Chronic osteomyelitis: diagnosis, treatment, prophylaxis]. Sibirskoe Meditsinskoe Obozrenie, 2009, no. 6, pp. 12-15. (in Russian)

3. Mironova O.V., Iatuev M.A., Chekmareva D.V., Golovacheva T.V., Lysov A.E. Khronicheskii osteomielit i nekotorye prichiny ego razvitiia [Chronic osteomyelitis and some causes of its development]. Materialy Ros. Simp. Detskikh khirurgov s mezhdunar. uchastiem "Priobretennaia Kishechnaia Neprokhodimost u Detei" [Proc. Russian Symposium of Children Surgeons with international participation “Acquired Intestinal Obstruction in Children”]. Meditsinskii Vestnik Severnogo Kavkaza, 2009, no. 1, pp. 103. (in Russian)

4. Eshmatov A.R. Analiz gnoino-vospalitelnykh oslozhnenii operativnogo lecheniia perelomov kostei skeletal tekhnologicheskogo geneza [Analysis of purulent-inflammatory complications of surgical treatment of skeletal bone fractures of technological genesis]. Vestnik Kyrgyzskoi Gosudarstvennoi Meditsinskoi Akademii im. I.K. Akhunbaeva, 2016, no. 1, pp. 111-114. (in Russian)

5. Kliushin N.M., Ababkov Iu.V., Ermakov A.M. Paraproteznaia infektsiia kak prichina revizionnykh vmeshatelstv posle totalnogo endoprotezirovaniia kolennogo sustava: etiologiia, diagnostika, lechenie [Paraposthetic infection as a cause of revision interventions after total arthroplasty of the knee: etiology, diagnosis, treatment]. Zabaikalskii Meditsinskii Vestnik. 2015, no. 2, pp. 189-197. (in Russian) Available at: zabmedvestnik.ru (accessed 11.06.2019).

6. Kliushin N.M., Sudnitsyn A.S., Subramanyam K.N., George J. Management of Neurologic Deformity of the Ankle and Foot With Concurrent Osteomyelitis With the Ilizarov Method. Foot Ankle Int., 2018, vol. 39, no. 2, pp. 226-235. DOI: 10.1177/1071100717739396.

7. Baptista M.S., Tardivo J.P., eds. Osteomyelitis. In Tech, 2012, 188 p. DOI: 10.5772/1264.

8. Vasileva N.V., Klimko N.N., Tsinzerling V.A. Diagnostika i lechenie invazivnykh mikozov: sovremennye rekomendatsii [Diagnosis and treatment of invasive mycoses: modern recommendations]. Vestnik Sankt-Peterburgskoi Meditsinskoi Akademii Poslediplomnogo Obrazovaniia, 2010, vol. 2, no. 4, pp. 5-18. (in Russian)

9. Kliushin N.M., Sudnitsyn A.C., Migalkin N.S. Blastomikoznyi osteomielit piatochnoi kosti (sluchai iz praktiki) [Calcaneal blastomycotic osteomyelitis (A case report)]. Genij Ortopedii, 2016, no. 3, pp. 84-86. (in Russian) 
10.Shevtsov V.I., Migalkin N.S., Kliushin N.M., Lapynin A.I., Degtiariov V.E. Redkii sluchai gistoplazmoza v ortopedii [An unusual case of histoplasmosis in orthopaedics]. Genij Ortopedii, 2003, no. 1, pp.130-131. (in Russian)

11.Jain R., Singh K., Lamzabi I., Harbhajanka A., Gattuso P., Reddy V.B. Blastomycosis of bone: a clinicopathologic study. Am. J. Clin. Pathol., 2014, vol. 142, no. 5, pp. 609-616. DOI: 10.1309/AJCPG2CFGHZ4URLN.

12.Ferreira L.C., Barroso P.F., Tonomura E., Akiti T., Rodrigues K.M. Osteomyelitis caused by Sporothrix schenckii in an immunocompetent patient. Rev. Soc. Bras. Med. Trop., 2016, vol. 49, no. 4, pp. 527-529. DOI: 10.1590/0037-8682-0354-2015.

13.Alvarenga J.A., Martins D.E., Kanas M., Elizeche H.G., Dell’Aquila A.M., Fernandes E.A., Wajchenberg M., Puertas E.B. Paracoccidioidomycosis in the spine: case report and review of the literature. Sao Paulo Med. J., 2016, vol. 134, no. 3, pp. $263-267$. DOI: 10.1590/1516-3180.2015.02691801.

14.Cohen S.H., Gerding D.N., Johnson S., Kelly C.P., Loo V.G., McDonald L.C., Pepin J., Wilcox M.H.; Society for Healthcare Epidemiology of America; Infectious Diseases Society of America. Clinical practice guidelines for Clostridium difficile infection in adults: 2010 update by the society for healthcare epidemiology of America (SHEA) and the infectious diseases society of America (IDSA). Infect. Control Hosp. Epidemiol., 2010, vol. 31, no. 5, pp. 431-455. DOI: 10.1086/651706.

15.Gamaletsou M.N., Rammaert B., Bueno M.A., Moriyama B., Sipsas N.V., Kontoyiannis D.P., Roilides E., Zeller V., Prinapori R., Taj-Aldeen S.J., Brause B., Lortholary O., Walsh T.J. Aspergillus osteomyelitis: epidemiology, clinical manifestations, management, and outcome. J. Infect., 2014, vol. 68, no. 5, pp. 478-493. DOI: 10.1016/j.jinf.2013.12.008.

16.Gamaletsou M.N., Walsh T.J., Sipsas N.V. Epidemiology of Fungal Osteomyelitis. Current Fungal Infection Reports, 2014, vol. 8, no. 4, pp. 262-270. Available at: https://doi.org/10.1007/s12281-014-0200-3.

17.Richaud C., De Lastours V., Panhard X., Petrover D., Bruno F., Lefort A. Candida vertebral osteomyelitis (CVO) 28 cases from a 10-year retrospective study in France. Medicine, 2017, vol. 96, no. 31, pp. e7525. DOI: 10.1097/MD.0000000000007525.

18.Schaper N.C., Andros G., Apelqvist J., Bakker K., Lammer J., Lepantalo M., Mills J.L., Reekers J., Shearman C.P., Zierler R.E., Hinchliffe R.J.; International Working Group on Diabetic foot. Specific guidelines for the diagnosis and treatment of peripheral arterial disease in a patient with diabetes and ulceration of the foot 2011. Diabetes Metab. Res. Rev., 2012, vol. 28, no. Suppl. 1, pp. 236-237. DOI: 10.1002/dmrr.2252.

19.Dobrynin V.M., Dobrynina I.A., Katsalukha V.V., Khlopunova O.V., Badikov V.D., Sivolodskii E.P., comp. Metodicheskie rekomendatsii po mikrobiologicheskoi diagnostike ranevykh infektsii v lechebno-diagnosticheskikh uchrezhdeniiakh armii i flota [Technique manual on the microbiological diagnosis of wound infections in medical-and-diagnostic institutions of the army and navy]. SPb., Savozh, Gl. Voen.-Med. Upr., 1999, 75 p. (in Russian)

Received: 22.05.2019

\section{Information about the authors:}

1. Anatolii S. Sudnitsyn, M.D., Ph.D., Russian Ilizarov Scientific Center for Restorative Traumatology and Orthopaedics, Kurgan, Russian Federation, Email: anatol_anatol@mail.ru

2. Nikolai M. Kliushin, M.D., Ph.D.,

Russian Ilizarov Scientific Center for Restorative Traumatology and Orthopaedics, Kurgan, Russian Federation, Email: klyushin_nikolay@mail.ru

3. Nikolai S. Migalkin,

Russian Ilizarov Scientific Center for Restorative Traumatology and Orthopaedics, Kurgan, Russian Federation

4. Tatyana A. Stupina, Ph.D. of Biological Sciences,

Russian Ilizarov Scientific Center for Restorative Traumatology and Orthopaedics, Kurgan, Russian Federation, Email: StupinaSTA@mail.ru

5. Tatyana N. Varsegova, Ph.D. of Biological Sciences,

Russian Ilizarov Scientific Center for Restorative Traumatology and Orthopaedics, Kurgan, Russian Federation, Email: varstn@mail.ru

6.Zinaida S. Naumenko, Ph.D. of Biological Sciences,

Russian Ilizarov Scientific Center for Restorative Traumatology and Orthopaedics, Kurgan, Russian Federation

7. Vyacheslav D. Gayuk, M.D.,

Russian Ilizarov Scientific Center for Restorative Traumatology and Orthopaedics, Kurgan, Russian Federation 